https://doi.org/10.37208/tgn27324

\section{Unusual aquatic vertebrates in the Firth of Forth, Scotland, during 2020: swordfish and northern bottlenose whales}

\author{
C.J. McInerny ${ }^{1} \&$ K. Hoey ${ }^{2}$ \\ ${ }^{1}$ School of Life Sciences, University of Glasgow, \\ Glasgow G12 8QQ \\ ${ }^{2} 23$ Dempsey Road, Bellshill, North Lanarkshire \\ ML4 2UF
}

${ }^{1}$ E-mail: chris.mcinerny @ glasgow.ac.uk

During 2020 there were two exceptional observations of aquatic vertebrates in the Firth of Forth, with both creatures seen off Lothian. This Short Note describes these events.

The first observation was of a swordfish (Xiphias gladius), the fourth live record of the species in Scottish waters (Birdguides, 2020; British Marine Life Study Society, 2021). It was first reported off Musselburgh in early July but was subsequently relocated $3 \mathrm{~km}$ to the east at Joppa on 3rd July, where it was seen until at least the 15th (Fig. 1). The swordfish would come in close at high tide, sometimes just $100 \mathrm{~m}$ from the shore, but was also seen further offshore when it appeared to hunt.

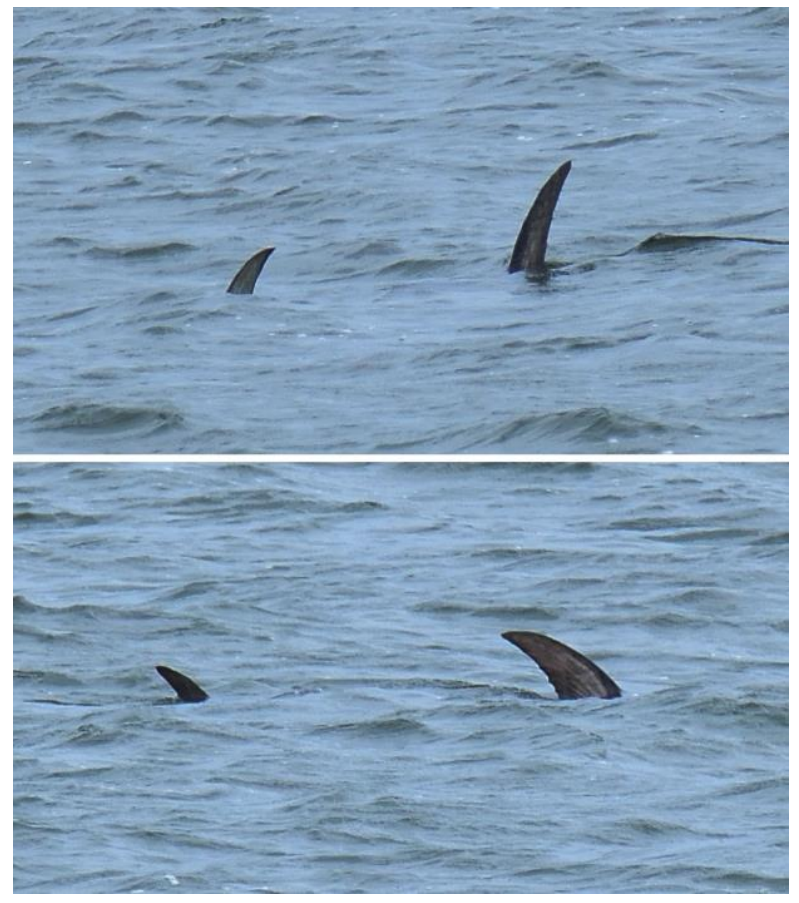

Fig. 1. Swordfish (Xiphias gladius), Joppa, Lothian, Scotland, 7th July 2020. (Photos: D. Morrison)
Swordfish are large, migratory, predatory fish characterised by a long, flat, pointed bill, and a prominent dorsal fin and tail, which can been seen above water when the fish swims near the surface (Fig. 1). They can grow up to $3 \mathrm{~m}$ in length and $650 \mathrm{~kg}$ in weight; this was the approximate size of the Joppa individual. The species has a cosmopolitan distribution, present in tropical and temperate areas of the Atlantic, Pacific, and Indian Oceans, being found from near the surface to depths of around $500 \mathrm{~m}$ (Froese \& Pauly, 2021). However, it is rare in the North Atlantic, with just five records elsewhere in the U.K., all in the Bristol Channel (NBN Atlas, 2021), and four in Scottish waters: Firth of Lorne, Argyll, October 1996; Loch Long, Argyll, 15th August 1997 (shoreline corpse); River Forth at Alloa, Clackmannanshire, 4th October 2009; and Seagreen offshore wind farm, off Montrose, Angus, August 2019 (Birdguides, 2020; British Marine Life Study Society, 2021).

The second observation was of two northern bottlenose whales (Hyperoodon ampullatus) seen off South Queensferry on 25th August (Fig. 2). They were watched swimming east out of the Firth by the authors, just east of the Forth Bridge.

Northern bottlenose whales are endemic to the North Atlantic where they are a deep-water cetacean species with a fragmented distribution (Hooker \& Baird, 1999; Gowans et al., 2001; Whitehead \& Hooker, 2012). Thus they are rarely seen in Scottish coastal waters with just over 20 records since 2000 (NBN Atlas, 2021), although up to five were present in the Firth of Clyde during the summer and autumn of 2020 (see O'Reilly \& Payne, 2021). Furthermore, the U.K. Cetacean Strandings Investigation Programme database indicates that there have been 52 stranded northern bottlenose whales in Scotland since 1989 (N. Davison, pers. comm.).

The Queensferry whales were seen during very inclement weather with heavy rain and north-east force 6-8 winds. These conditions resulted in pelagic seabirds such as 17 long-tailed skuas (Stercorarius longicaudus), two pomarine skuas ( $S$. pomarinus) and three sooty shearwaters (Ardenna grisea), normally only seen in the open ocean, also being observed in the upper Firth of Forth on 25th August at the same site. Thus this severe weather may explain the presence of the whales. However, it has been suggested that human activities, in particular military sonar signals, are affecting whale behaviour (Parsons, 2017; Wensveen et al., 2019), which might account for their presence close to land and in shallow water.

We thank Dennis Morrison for use of his images shown in Fig. 1. 

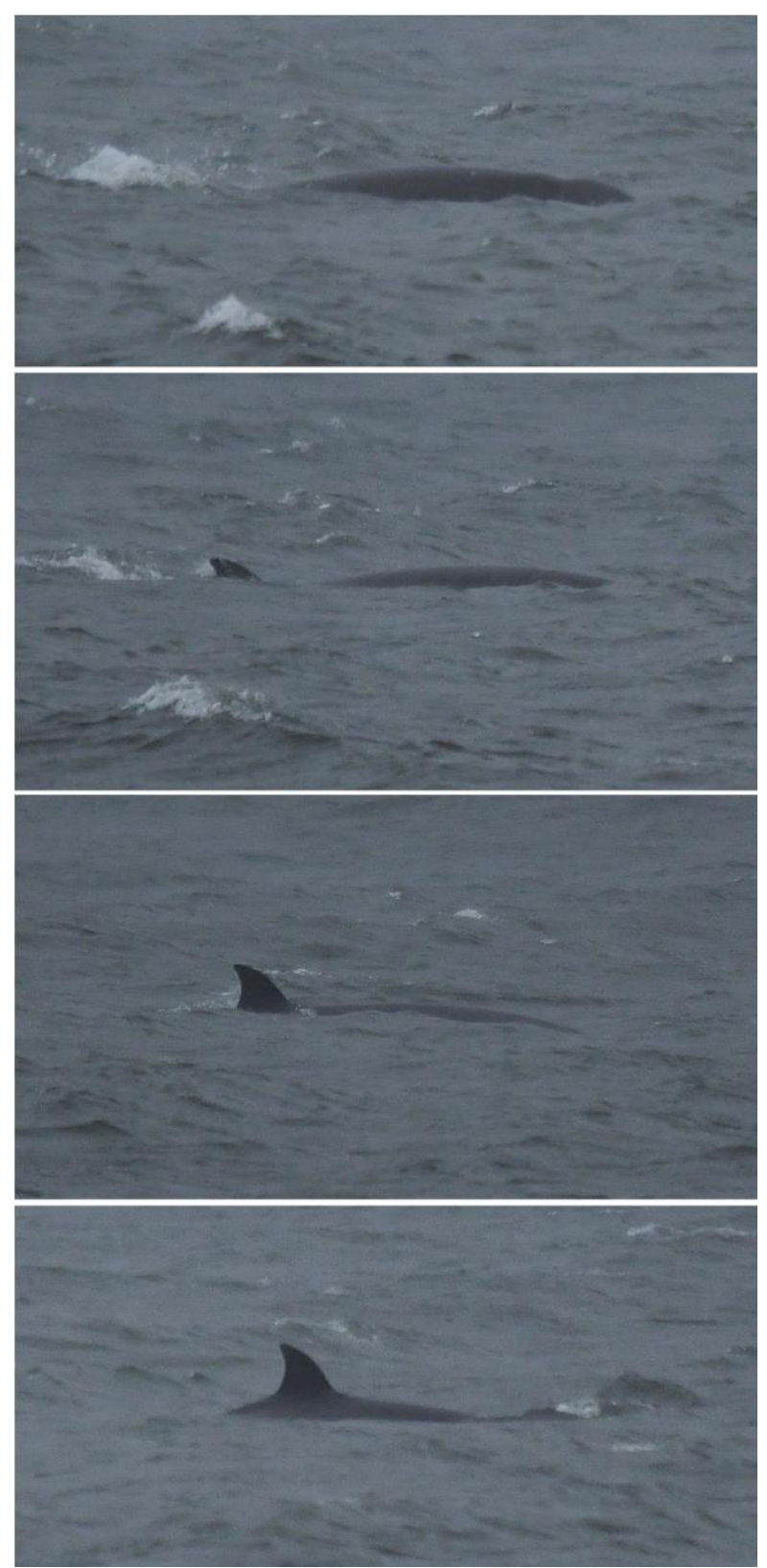

Fig. 2. Northern bottlenose whale (Hyperoodon ampullatus), one of two, South Queensferry, Lothian, Scotland, 25th August 2020. These cetaceans were identified by their size, colour, bulbous foreheads, beaks, and long flat backs with a small falcate fin two-thirds of the way towards the tail. (Photos: K. Hoey)

\section{REFERENCES}

Birdguides (2020). Second-ever swordfish confirmed from Scottish waters.

https://www.birdguides.com/news/second_ever_sw ordfish-confirmed-from-scottish-waters/

British Marine Life Study Society (2021). Swordfish and Blue Marlin Reports (British Seas). http://glaucus.org.uk/Swordf.htm Accessed 9th March 2021.

Froese, R. \& Pauly, D. (Editors) (2021). FishBase. https://www.fishbase.de/summary/Xiphiasgladius.html

Gowans, S., Whitehead, H. \& Hooker, S.K. (2001). Social organization in northern bottlenose whales,
Hyperoodon ampullatus: not driven by deep-water foraging? Animal Behaviour 62, 369-377. https://doi.org/10.1006/anbe.2001.1756

Hooker, S.K. \& Baird, R.W. (1999). Deep-diving behaviour of the northern bottlenose whale, Hyperoodon ampullatus (Cetacea: Ziphiidae). Proceedings of the Royal Society of London B: Biological Sciences 266, 671-676. https://doi.org/10.1098/rspb.1999.0688

National Biodiversity Network (NBN) Atlas (2021). http://www.nbnatlas.org Accessed 24th January 2021.

O'Reilly, M. \& Payne, A.P. (2021). Bottlenose whales in the Clyde Sea Area, Scotland in 2020. The Glasgow Naturalist 27(3), 108-111.

Parsons, E.C.M. (2017). Impacts of navy sonar on whales and dolphins: now beyond a smoking gun? Frontiers in Marine Science 4, 295. https://doi.org/10.3389/fmars.2017.00295

Wensveen, P., Isojunno, S., Hansen, R.R., von BendaBeckmann, A.M., Kleivane, L., van IJsselmuide, S. et al. (2019). Northern bottlenose whales in a pristine environment respond strongly to close and distant navy sonar signals. Proceedings of the Royal Society B: Biological Sciences 286, 20182592. https://doi.org/10.1098/rspb.2018.2592

Whitehead, H. \& Hooker, S.K. (2012). Uncertain status of the northern bottlenose whale Hyperoodon ampullatus: population fragmentation, legacy of whaling and current threats. Endangered Species Research 19, 47-61.

https://doi.org/10.3354/esr00458 